\title{
MIGRATION OF INSOLUBLE AND SOLUBLE IMPURITIES IN TEMPERATE ICE: STUDY OF A VERTIGAL ICE PROFILE THROUGH THE GLACIER DU MONT DE LANS (FRENCH ALPS)
}

\author{
By M. RicQ-De BOUARD* \\ (Université Scientifique et Médicale de Grenoble, Institut de Géographie Alpine, rue \\ Maurice-Gignoux, 38031 Grenoble Cedex, France.)
}

\begin{abstract}
Ice samples representing at least some twenty years' accumulation, have been collected from a crevasse wall at $3200 \mathrm{~m}$ (Glacier du Mont de Lans, Massif de l'Oisans), with a view to studying the behaviour of soluble and insoluble impurities in temperate ice. The stratification of the ice from the surface to $2 \mathrm{~m}$ and the disappearance of this stratification below $2 \mathrm{~m}$ are attributed to a variation in the glacier regime on both sides of the equilibrium line, rather than to a variation in the conditions of deposit of solid debris on the glacier surface, the strata do not necessarily correspond to an annual accumulation. Mineralogical analysis of the solid particles has allowed us to demonstrate two kinds of deposit: that consisting of the local Alpine material (hornblende) and that consisting of a mixture of local material and red sand of Saharan origin (anatase). A study of the distribution of major cations ( $\mathrm{Na}, \mathrm{K}, \mathrm{Mg}, \mathrm{Ca}$ ) along a profile has revealed the existence of a process of leaching which follows an exponential law to a first approximation. The leaching produces a rapid evolution in the chemical properties of the ice compared with those of the original precipitation.
\end{abstract}

RÉsumÉ. Migration des impuretés insolubles et solubles dans le glace tempérée: étude d'un profil vertical de glace au glacier du Mont de Lans (Alpes franf̧aises). Des échantillons de glace, représentant au moins une vingtaine d'années d'accumulation, ont été prélevées sur la paroi d'une crevasse à $3200 \mathrm{~m}$ (glacier du Mont de Lans, (Massif de l'Oisans), en vue de l'étude du comportement des éléments solubles et insolubles dans la glace tempérée. La stratification de la glace de la surface à $2 \mathrm{~m}$ et la disparition de cette stratification au dessous de $\mathbf{2} \mathbf{~ m}$ a été attribuée à une variation du régime du glacier de part et d'autre de la ligne d'équilibre plutôt qu'à une variation des conditions de dépôts des débris solides à la surface du glacier, les strates ne correspondent pas forcément à une accumulation annuelle. L'analyse minéralogique des éléments solides a permis de mettre en évidence deux types de dépôts: ceux constitués par du matériel local alpin (hornblende) et ceux constitués par le mélange de matériel local et de sables rouges d'origine saharienne (anatase). L'étude de la répartition des cations majeurs $(\mathrm{Na}, \mathrm{K}, \mathrm{Mg}, \mathrm{Ca})$ le long du profil a révélé l'existence de processus de lessivage qui se ferait suivant une loi exponentielle en première approximation. Ce lessivage entraîne une évolution rapide des propriétés chimiques de la glace par rapport à celles des précipitations originelles.

Zusammenfassung. Wanderung unlöslicher und löslicher Verunreinigungen in temperiertem Eis: Untersuchung eines vertikalen Eisprofiles durch den Glacier du Mont de Lans, französische Alpen. Eisproben von mindestens 20 Jahre Alter wurden aus einer Spaltenwand in $3200 \mathrm{~m}$ Höhe am Glacier du Mont de Lans im Massif de l'Oisans entnommen, um das Verhalten löslicher und unlöslicher Verunreinigungen in temperiertem Eis zu untersuchen. Die Schichtung des Eises von der Oberfläche bis $2 \mathrm{~m}$ Tiefe und das Verschwinden der Schichtung unterhalb dieser Tiefe wird eher auf eine Veränderung des Gletscherverhaltens beiderseits der Gleichgewichtslinie zurückgeführt, als auf einen Wechsel der Ablagerungsbedingungen für festen Schutt auf der Gletscheroberfläche, da die Schichten nicht streng einer Jahresakkumulation entsprechen. Die mineralogische Analyse der festen Partikel führt zum Nachweis zweier verschiedener Ablagerungsarten: lokales alpines Material (Hornblende) und alpines Material vermischt mit rotem Sand aus der Sahara (Anatase). Eine Studie der Verteilung der grösseren Kationen ( $\mathrm{Na}, \mathrm{K}, \mathrm{Mg}, \mathrm{Ca}$ ) längs eines Profiles führte zur Feststellung eines Sickerungsprozesses, der in erster Annäherung einem Exponentialgesetz folgt. Diese Sickerung hat eine schnelle Veränderung der chemischen Eigenschaften des Eises, verglichen mit denen des ursprünglichen Niederschlages, zur Folge.

\section{INTRODUGTION}

Temperate ice is a complicated material consisting of a solid and a liquid phase in thermodynamic equilibrium and whose chemical properties evolve with time. According to Glen and others (in press), recrystallization phenomena assist the migration of impurities to grain boundaries and then these impurities are progressively eliminated from the glacier along the veins within the ice. France.

* Present address: Centre de Recherches Archéologiques du CNRS, Sophia-Antipolis, o656o Valbonne, 
Chemical studies of temperate ice have mainly hitherto been conducted in the course of dating experiments using radioactive isotopes, and there exist few results on the behaviour of ions and solid particles although these in fact determine the radioactivity measurements mentioned above.

The study of chemical processes within a glacier has nevertheless been undertaken by Gorham (1958) with his analysis of variations in the chemical composition of ice on a crevasse wall from the surface to $14 \mathrm{~m}$. This author does not observe any systematic reduction with depth in the concentration of $\mathrm{Na}, \mathrm{K}, \mathrm{Mg}, \mathrm{Ca}, \mathrm{HCO}_{3}, \mathrm{Cl}, \mathrm{SO}_{4}$ and thus no leaching. $\mathrm{He}$ attributes the concentration variations, which are in the same sense for all the ions, to changes in the structure and density of ice and hence to climatic variations. Measurements of radioactivity made by Picciotto and others ( 1967 ) on firn and ice samples from Kesselwandferner (Austria) have also given some information on the behaviour of strontium and lead. $90 \%$ of the ${ }^{90} \mathrm{Sr}$ present in precipitation had been leached from the firn and had not been reabsorbed in the underlying ice. ${ }^{210} \mathrm{~Pb}$ on the other hand was displaced neither in the firn nor the ice where measurements of its activity therefore allowed a valuable means of dating, at least for the recent ice on which these observations were made. The difference in behaviour between strontium and lead is partly explained by their different chemical properties. According to Ambach and others (1969) the displacement of solid matter will be slight in the firn, causing a weak leaching of total $\beta$ activity connected with absorption on these materials.

By detailed chemical study of an ice cliff of the Glacier du Mont de Lans, situated at an altitude of $3200 \mathrm{~m}$ a.s.l. near the equilibrium line, I have tried to obtain new data for this research on chemical mechanisms in ice in the neighbourhood of $0^{\circ} \mathrm{C}$.

\section{Sample Gollection and anAlysis}

The Glacier du Mont de Lans, where the samples were collected, is situated in the Massif de l'Oisans Pelvoux. It has been described by Vivian and Volle (1970) as a real glacier cupola, with a convex transverse profile which sends tongues radiating in all directions. The areas of overhanging rock walls is negligible, which results in a very small accumulation of surface debris. Together with the Glacier de la Girose it makes up the most westerly glacial group of the massif. Partly because of its orientation and partly because of its high elevation $(80 \%$ of its surface area occurs above the equilibrium line which is at $3000 \mathrm{~m}$ a.s.l. in this massif) it enjoys a good snow accumulation from westerly winds responsible for snowfalls which build up to 3 to $4 \mathrm{~m}$ each year.

The western tongue of the glacier, or Jandri tongue, has been chosen as the place for sampling because of its rapid accessibility by telecabines. The sampling was done at the end of September 1975 in a transverse crevasse situated up-glacier from a relatively crevassed zone corresponding to a slight break of slope of the glacier and about $500 \mathrm{~m}$ from the snout. This crevasse was some $20 \mathrm{~m}$ long and $8 \mathrm{~m}$ in average depth including an uphill vertical wall on which the sampling was done and a downhill subvertical wall with knobs of refrozen ice. Below the top $5 \mathrm{~cm}$, corresponding to a recent snowfall, the wall consisted of ice. Black layers rich in solid matter regularly spaced every $30 \mathrm{~cm}$ marked the cliff to a depth of $2 \mathrm{~m}$. These layers presumably correspond to the spring melt period and seem therefore to mark the annual layers. Below $2 \mathrm{~m}$ the stratification was no longer visible, which poses the question as to why it disappears so suddenly.

The samples were taken using an instrument of the hammer ice-axe type in large blocks so as to reduce as much as possible the contact points between the instrument and the sample which was then immediately placed in a polyethylene bag. Thirty-eight samples were obtained in this manner every $30 \mathrm{~cm}$ to $2 \mathrm{~m}$ and then every $20 \mathrm{~cm}$ to $6.5 \mathrm{~m}$. It is estimated that they represent at least some twenty years of accumulation. They were transported in solid form to the laboratory, where they were kept at $-10^{\circ} \mathrm{C}$ until they were wanted for analysis. 
Solid matter, extracted by filtering the water through $0.3 \mu \mathrm{m}$ milipore filters, was weighed, observed with binocular and polarizing microscopes, and analysed chemically. The Na, K and $\mathrm{Mg}$ content of the filtered waters was determined by atomic flame absorption by spectrophotometry after preliminary concentration (by a factor 16 ) on ion-exchange resins (Ricq-de Bouard, 1976). Ca was determined directly after filtration.

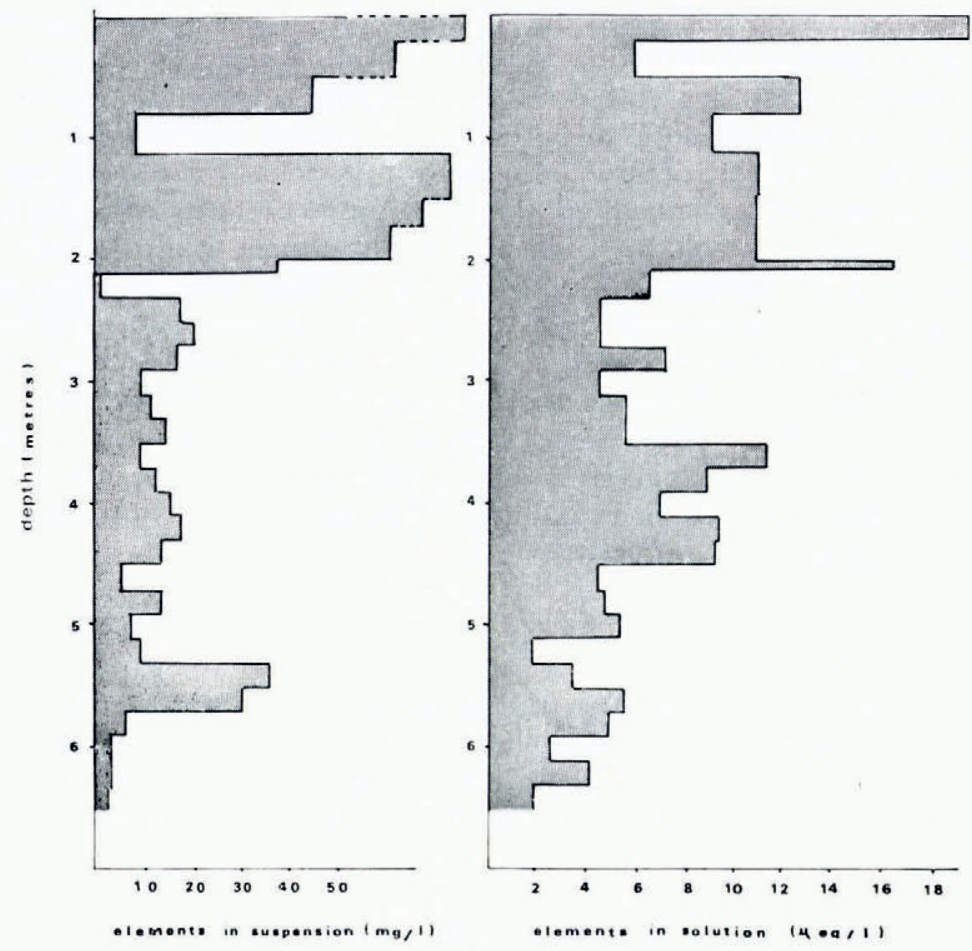

Fig. I. Variation in concentration of suspended and dissolved matter with depth.

\section{RESUlts}

\section{Insoluble elements}

The amount of matter suspended in the ice is very significant between 5 and $30 \mathrm{~cm}$ (3I0 mg/1), then it decreases markedly while showing variations (Fig. I). Down to 2. I $\mathrm{m}$ it is localized in the clearly visible strata, as has been described above. Below 2.10 $\mathrm{m}$ it varied from 5 to $20 \mathrm{mg} / \mathrm{l}$ and is relatively uniformly distributed throughout the ice, with, however, a well defined maximum between 5.30 and $5.70 \mathrm{~m}(40-45 \mathrm{mg} / \mathrm{l})$, a maximum which does not correspond in any clear way with an increase in the major cations in solution.

The horizon between 2.00 and $2.10 \mathrm{~m}$, particularly rich in matter in suspension and in solution, marks the boundary between the stratified zone above and the unstratified zone below. We shall see below that these two zones are differentiated not only by the quantity and distribution of solid matter but equally by the behaviour of their sodium and potassium content in solution.

The solid deposits present in the ice are fines, below $50 \mu \mathrm{m}$. Their colour allows their classification into two groups. The first are dark grey ( $10 \mathrm{Y} / \mathrm{R}_{4}$ in the Munsell Soil Color Charts, Munsell Color Company Inc., Baltimore, Maryland 2 I2 18, U.S.A.), the others grey 
Table I. Mass loss and $\mathrm{Fe}_{2} \mathrm{O}_{3}$ COntent of Solid matter

$\begin{array}{ccc}\text { Colour } & \text { Loss at } \mathrm{I} \mathrm{Ooo}^{\circ} \mathrm{C} & \mathrm{Fe}_{2} \mathrm{O}_{3} \\ & \% & \% \\ \text { Io } \mathrm{Y} / \mathrm{R}_{4} & 15 & 6.1 \\ \text { Io } \mathrm{Y} / \mathrm{R}_{4} / 2 & 20 & 8.5\end{array}$

brown (10 Y/R 4/2 in the Munsell Soil Color Charts). From the chemical point of view they are principally distinguished by their loss at $\mathrm{I} 000^{\circ} \mathrm{C}$ and their $\mathrm{Fe}_{2} \mathrm{O}_{3}$ content (Table I).

Few of the minerals were identifiable in the polarizing microscope because of their size. Nevertheless it was possible to note the presence of several hornblendes in the ro Y/R 4 and of anatases in the $10 \mathrm{Y} / \mathrm{R}_{4 / 2}$ deposit. This latter mineral is very resistant and is generally found to be concentrated in ancient sands which have undergone many reworkings, whereas hornblende is an Alpine mineral which is peculiarly abundant in all deposits coming from the inner zone of the Alps. Despite the limited number of these results as regards the number of observations made we can consider that the ro $\mathrm{Y} / \mathrm{R}_{4}$ deposits consist of local material, while the Io $\mathrm{Y} / \mathrm{R}_{4} / 2$ deposits, richer in $\mathrm{Fe}_{2} \mathrm{O}_{3}$ and containing anatase, come from a mixture of local material and red sand of Saharan origin frequently observed in the Alps (Clément and others, 1972). The Io Y/R $4 / 2$ deposits are present in strata from 0.50 to $0.80 \mathrm{~m}$, o.80 to I. Io $\mathrm{m}$ and 4 . Io to $4.50 \mathrm{~m}$. The analysis of solid deposits present in the ice thus appears as a method of identification, and perhaps eventually of dating, of certain horizons, if it is possible to relate a type of deposit to an historical event.

\section{Major elements in solution}

Apart from the layer from 1.50 to $2.00 \mathrm{~m}$, calcium is always the dominant element, which indicates a terrestrial origin for most of the soluble impurities (Fig. 2). A comparison between the concentrations of cations in the different horizons analysed has shown that there exists a linear correlation between $\mathrm{Na}$ and $\mathrm{K}$, and between $\mathrm{Ca}$ and $\mathrm{Mg}$, the linear equation being

$$
c_{\mathrm{Na}}=\mathrm{I} . \mathrm{I} 3^{c_{\mathrm{K}}}+\mathrm{I} .98 \mathrm{ng} / \mathrm{l}
$$

with a correlation coefficient of 0.93 for 26 specimens, and

$$
c_{\mathrm{Ca}}=6.90 c_{\mathrm{Mg}}+\mathrm{I} 9.07 \mathrm{ng} / \mathrm{l}
$$

with a correlation coefficient of 0.92 for 28 specimens.

Certain specimens are significantly divergent from this trend, and these have not been taken into account in computing the linear coefficients. This occurs for $\mathrm{Na}$ in the two samples between I. IO and $2.00 \mathrm{~m}$, a very special horizon as far as sodium is concerned as we shall see below, and for $\mathrm{Ca}$ in the samples between $\mathrm{r}$. 10 and $1.45 \mathrm{~m}$ and between 3.50 and $3.70 \mathrm{~m}$. These correlations indicate identical behaviour of the two alkalis and of the two alkaline earths and, if not an identity of origin, at least a simultaneity of deposit of $\mathrm{Na}$ with $\mathrm{K}$ and $\mathrm{Ca}$ with $\mathrm{Mg}$.

The linear correlation coefficients between the other cations are very weak (Table II).

Table II. Correlation coefficients between concentrations of CERTAIN CATIONS

$\begin{array}{lccc}\text { Cations } & \begin{array}{c}\text { Correlation } \\ \text { coefficient }\end{array} & \begin{array}{c}\text { Number of } \\ \text { measurements }\end{array} & \text { Samples eliminated } \\ \mathrm{Na}, \mathrm{Mg} & 0.68 & 26 & 0-0.20 \mathrm{~m}, \mathbf{1 . 4 5}-\mathbf{1 . 7 0} \mathrm{m} \\ \mathrm{Na}, \mathrm{Ca} & 0.2 \mathrm{I} & 28 & 0-0.20 \mathrm{~m} \\ \mathrm{Ca}, \mathrm{K} & 0.53 & 30 & \\ \mathrm{~K}, \mathrm{Mg} & 0.55 & 30 & \end{array}$




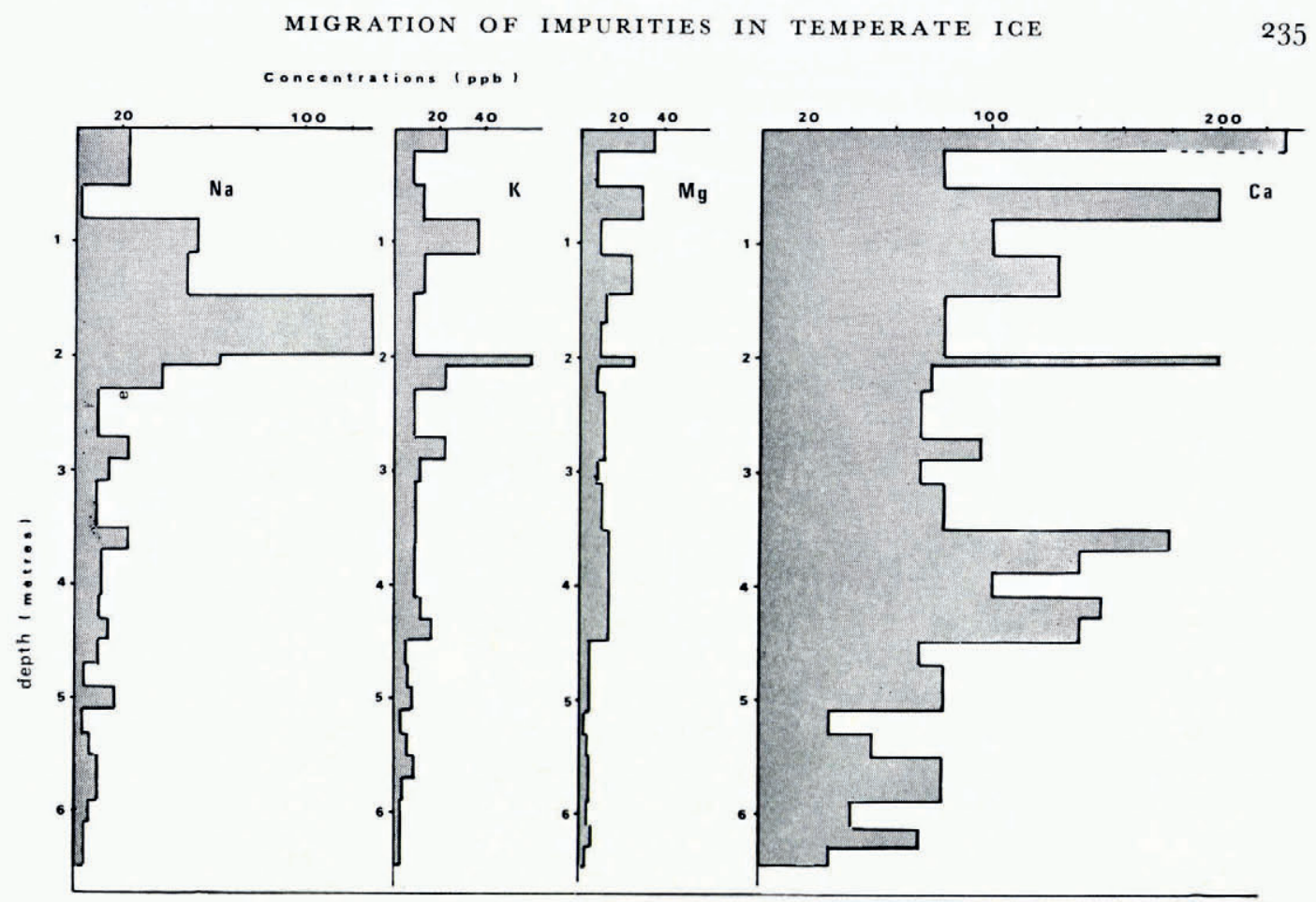

Fig. 2. Variation in concentration of major cations with depth.

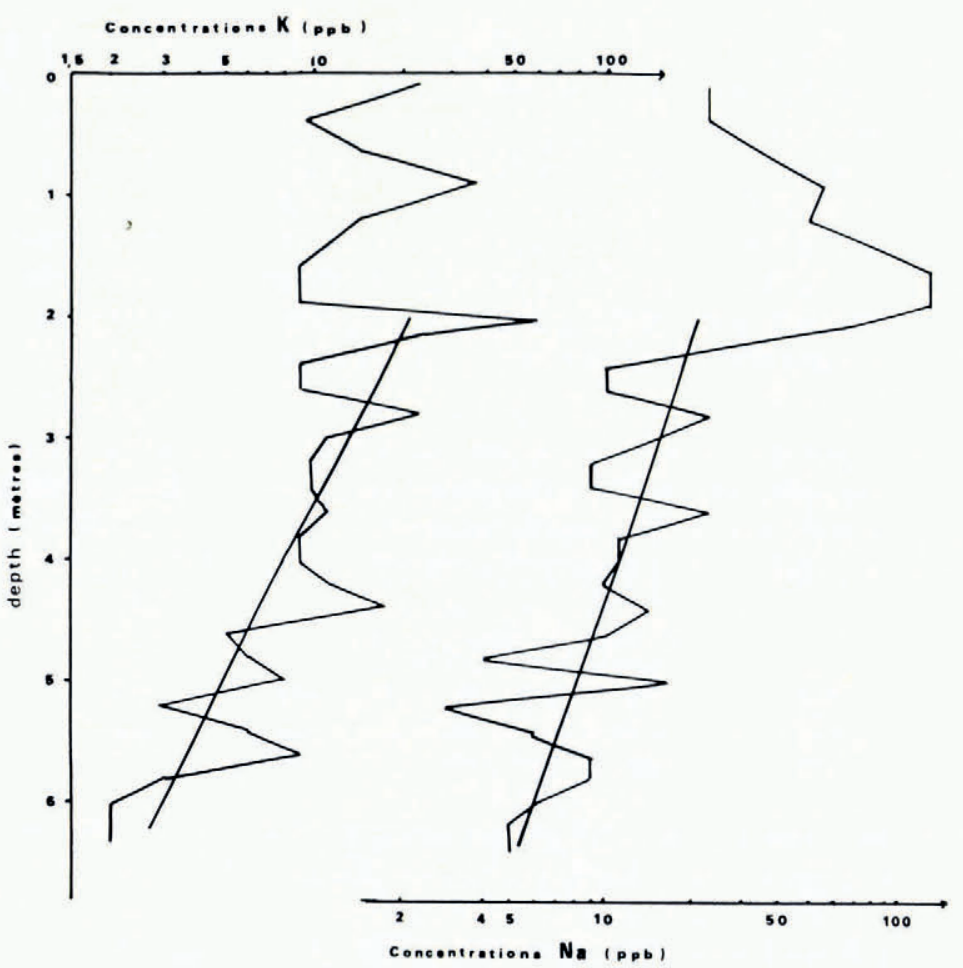

Fig. 3. Semi-logarithmic plot of the variation of concentration of sodium and potassium with depth. 


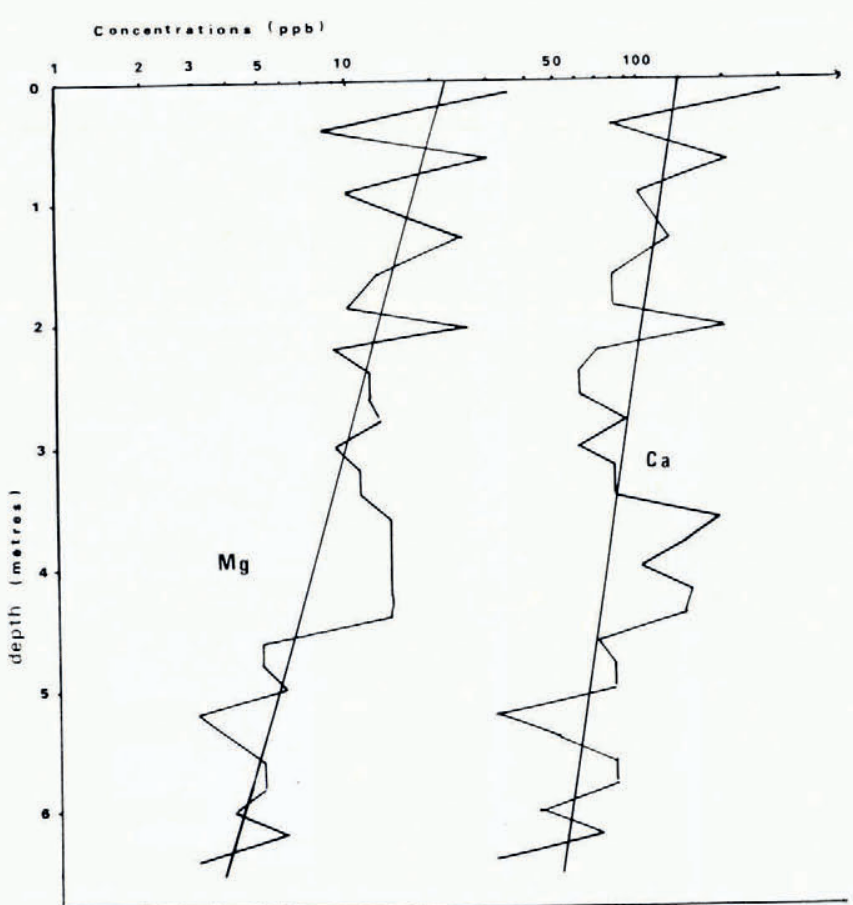

Fig. 4. Semi-logarithmic plot of the variation of concentration of magnesium and calcium with depth.

The concentration variations of $\mathrm{Na}$ and $\mathrm{K}$ on the one hand and of $\mathrm{Ca}$ and $\mathrm{Mg}$ on the other do not always occur in the same sense, that is to say the maxima and minima of concentration do not coincide for the four cations (Fig. 2). However the clearest result which emerges from the data on Figure 2 is the general tendency for concentrations to decrease from the surface to the base of the profile indicating a leaching of ions. I have tried to quantify this tendency. A semi-logarithmic plot of concentration variations of the different elements with depth (Figs 3-4) indicates to a first approximation a linear decrease of these elements, from the surface to the base of the profile for $\mathrm{Ca}$ and $\mathrm{Mg}$ and from 2.10 $\mathrm{m}$ to the base of the profile for $\mathrm{Na}$ and $\mathrm{K}$. The leaching therefore obeys a law of the form

$$
c=c_{0} \exp (-\lambda H)
$$

where $c$ is the concentration at depth $H, c_{0}$ the initial surface concentration and the leaching constant equal to $\log 2 / H_{\frac{1}{2}}$ where $H_{\frac{1}{2}}$ is the depth at which $c=\frac{1}{2} c_{0}$. More directly $\delta c$ in a given horizon is proportional to the concentration present, $\delta c=-\lambda_{c} \delta H$. Values of $H_{1}$ and $\lambda$ are different for the four cations analysed as shown in Table III.

Table III. Leaching constants

$\begin{array}{ccccc}\text { Cation } & \mathrm{Na} & \mathrm{K} & \mathrm{Mg} & \mathrm{Ca} \\ H_{1} \mathrm{~m} & 2.13 & \mathrm{1} .40 & 2.66 & 4.44 \\ \lambda \mathrm{m}^{-1} & 0.3^{2} & 0.49 & 0.26 & 0.16\end{array}$

According to these values the order of increasing leaching is $\mathrm{Ca}, \mathrm{Mg}, \mathrm{Na}, \mathrm{K}$. Note that the alkaline earths are less rapidly leached than the alkalis. Although the leaching rate of $\mathrm{K}$ is greater than that of $\mathrm{Na}$, while that of $\mathrm{Mg}$ is greater than that of $\mathrm{Ca}$, we have found a good correlation between $\mathrm{K}$ and $\mathrm{Na}$ and between $\mathrm{Mg}$ and $\mathrm{Ca}$. At first sight this seems contradictory, 
but it can be explained by the fact that the profile analysed is not very deep and that therefore the deviations related to differences in behaviour of the cations are not very important. The exponential law for concentration decrease with depth (and therefore time) is really only a first approximation. The linear correlation coefficients of the logarithms of concentration are only 0.67 for $\mathrm{Na}, 0.80$ for $\mathrm{K}, 0.76$ for $\mathrm{Mg}$, and 0.55 for $\mathrm{Ca}$. These relatively low values, particularly in the case of $\mathrm{Ca}$, are due to the fact that the initial concentrations $c_{0}$ for each horizon was not constant as is assumed in the theory, but underwent annual variations connected with the origin (marine or continental) of the precipitation as well as with general environmental conditions. Furthermore, in the analysis of variation of concentration with depth we have only considered the leaching process. However according to a previous study (Ricq-de Bouard and Thomas, in press) we have been able to show that, before the leaching stage there is a phase of sodium enrichment of a deep horizon in the snow cover. We have attributed to this phenomena the structure of that horizon, which allows us to capture the sodium coming from liquid precipitation. Similar processes seem able to explain the high sodium content observed between 0.90 and $2.00 \mathrm{~m}$.

\section{Conclusion}

This study of the distribution of major cations in ice shows clearly that the chemical properties of temperate ice are essentially conditioned by a leaching process* which removes the chemical constituents occurring in the original precipitation. As opposed to what occurs in cold ice, no chemical stratification exists in temperate ice at least as regards the major cations. This statement counsels prudence in dating attempts on such ice using stable or radioactive, natural or artificial isotopes. Nevertheless we have seen that the leaching rates seem to depend on the chemical properties of the cations. They could therefore probably be very small or zero for certain elements.

As far as the distribution and concentration of solid deposits is concerned, the observations made pose the question of the significance of the stratification visible in the ice. We have observed, in effect, an alternation of layers of ice poor and rich in suspended particles from the surface to $2 \mathrm{~m}$, then a sudden disappearance of all visible stratification.

The explanation of this phenomenon as due to an important change as a function of time and place of formation of the ice in the deposition of debris seems completely excluded when we can consider the topography of the glacier and the rarity of overhanging rock surfaces. The hypothesis of the leaching of these deposits is not satisfactory either; it does not explain the suddenness of the change from the upper zone down to $2 \mathrm{~m}$ to the zone below. By contrast a third hypothesis in terms of variations of regime of the glacier makes the observed phenomena coherent. Three types of situation could have occurred: (i) accumulation is always greater than ablation, (ii) accumulation is sometimes greater and sometimes less than ablation, (iii) accumulation is always less than ablation.

In the first type of situation two consecutive dark horizons correspond to two consecutive spring periods and measuring the interval between these two horizons gives a value of the annual accumulation. If the rates of debris accretion and accumulation are constant, the dark layers will occur at regular intervals and their content of suspended matter will be similar. In the third type of situation the solid matter in a single dark horizon can come from several consecutive summers. It then becomes impossible to relate the stratigraphy visible to the eye to a chronology. One can however still draw from the amount of debris contained in each horizon conclusions concerning the value of the ablation: a band particularly rich indicating the concentration of deposits from many years in a single horizon, and thus a considerable

* These conclusions are somewhat different from those of Gorham (1958). We can note that the chemical analyses whose results are presented by him were made on ice samples transported in liquid form (which increases the risk of contamination) and that the methods of analysis used were significantly less sensitive than those used in the present work. 
ablation (assuming, let us recall, a constant accretion of debris, which seems justified in the zone in question). The second type of situation, which appears in the neighbourhood of the equilibrium line, leads to a stratification which may or may not correspond to an annual stratification without our being able to decide which.

According to this hypothesis on the variation of glacier regime we can postulate that the bottom of the profile analysed, from 6.50 to $2.00 \mathrm{~m}$, consists of ice formed above the equilibrium line; the stratification not being visible in this zone because the annual accretion of debris is small. By contrast the ice between $2.00 \mathrm{~m}$ and the surface is formed in the neighbourhood of the equilibrium line or in the ablation zone. The concentration by ablation of the solid matter from several years allows a stratification to appear which ought not to be interpreted as resulting from an annual phenomenon. The high concentration of suspended matter between 5 and $30 \mathrm{~cm}$ corresponds to the importance of the ablation in recent years; an importance related to its position just below the equilibrium line rather than to any recent increase in the solid deposition at the glacier surface.

\section{Acknowledgements}

I would like to express my sincere thanks to S. Peguy and $\mathrm{H}$. Cortot who collected the ice specimens and whose collaboration has been indispensible for the success of this work.

MS. received I July 1976 and in revised form 2 September 1976

\section{REFERENGES}

Ambach, W., and others. 1969. Studies on vertical total-beta-activity; profiles of fission products in the accumulation area of the Stubacher Sonnblickkees (Hohe Tauern, Salzburg, Austria), by W. Ambach, H. Eisner, F. A. Prantl and H. Slupetzky. Pure and Applied Geophysics, Vol. 74, p. 83-91.

Clément, R., and others. I972. La neige colorée sur les Alpes françaises, [par] R. Clément, M. Ricq[-de Bouard] et A. Thomas. Direction de la Météorologie Nationale. Établissement d'Études et de Recherches Météorologiques (Paris), Note Interne No. 313.

Glen, J. W., and others. In press. Water at grain boundaries; its role in the purification of temperate glacier ice, by J. W. Glen, D. R. Homer and J. G. Paren. [Union Géodésique et Géophysique Internationale. Association Internationale des Sciences Hydrologiques. Commission des Neiges et Glaces. Proceedings of the International Symposium on Isotopes and Impurities in Snow and Ice, Grenoble, 28-30 August 1975. (IAHS-AISH Publication No. I 18).]

Gorham, E. 1958. The salt content of some ice samples from Nordaustlandet (North East Land), Svalbard. Fournal of Glaciology, Vol. 3, No. 23, p. $181-87$.

Picciotto, E. E., and others. 1967. Lead-2 1o and strontium-9o in an Alpine glacier, by E. [E.] Picciotto and G. Crozaz and W. Ambach and H. Eisner. Earth and Planetary Science Letters, Vol. 3, No. 3, p. $237-42$.

Ricq-de Bouard, M. 1976. A method of concentrating the major impurities contained in ice by ion exchange. fournal of Glaciology, Vol. 17, No. 75, p. 129-33.

Ricq-de Bouard, M., and Thomas, A. In press. Evolution chimique de la neige au sol. [Union Géodésique et Géophysique Internationale. Association Internationale des Sciences Hydrologiques. Commission des Neiges et Glaces. Proceedings of the International Symposium on Isotopes and Impurities in Snow and Ice, Grenoble, 28-30 August I975. (IAHS-AISH Publication No. 1 i 8).]

Vivian, R., and Volle, L. 1970. Fiches des glaciers français. Les glaciers du Mont de Lans et de la Girose. Revue de Géographie Alpine, Tom. 58, [Fasc.] 4, p. 689-92. 